I understand it was made specially for him.

Owing to being called up at short notice my own is in such a safe place I cannot find it. It consists of an ivory handle about three inches long containing a delicate spring controlled by a button lever, and the forceps portion extends to about one inch. The teeth open about an eighth of an inch when the spring is released. To insert the forceps, which are very fine and delicate as no crushing is required, the teeth are closed by pressing the lever with the forefinger, then they are opened by releasing the lever and closed firmly on the foreign body to hold it and withdraw it.

In view of the large numbers of intra-ocular foreign bodies in wartime, and my colleague Mr. L. H. Savin tells me many are a compound of magnesium and aluminium, I thought this instrument would be of interest to your readers-also I want to replace my own.

Yours faithfully,

J. MYLES BICKERTON,

Wing-Comdr.

Owls Oak, Denham, Bucks.

June 24, 1930.

\title{
MUSTARD GAS AND ITS IMPLICATIONS
}

\section{To the Editors of THE BRITISH JOURNAL OF OPHTHALMOLOGY}

SIRS,-With reference to the letter in your last issue from Sir James Barrett concerning Mustard Gas and its implications, we feel compelled to record a preliminary word of dissent, though at the moment it is not possible to amplify this.

Sir James' statements in his first paragraph are likely to convey a wrong impression because his analogy is false. It is illogical to compare the action of a substance causing local caustic damage, with that of one which requires absorption, and which acts at a distance from its site of application. Further, there are other, and more effective, methods of preventing the action of a substance instilled into the conjunctival sac than that of washing it out.

For the past few months we have been engaged in animal experimentation to investigate the efficacy of a new substance designed specifically for the purpose of combating the effects of mustard gas on the eye and elsewhere. Our results, on the eve of publication, have proved to our satisfaction that this is a substance whose immediate application is effective in oxidising, and thus neutralising the action of, mustard gas in the eye of the rabbit; it is, moreover, harmless to the human cornea, and we predict with 
confidence that on the eye of man contaminated with mustard gas, this substance will act with beneficial results in the majority of cases.

We have the honour to be, Sirs,

Your obedient servants,

$$
\begin{aligned}
& \text { JNO. EYRE, } \\
& \text { FRANK W. LAW. }
\end{aligned}
$$

P.S.-As regards the late effects of mustard gas injury to the eye, though perhaps "disastrous" is not too strong a word to apply, it must be admitted that the advent of diathermy and contact glasses into this field has entirely altered the outlook in these cases, and may be said to have brought them within the range of effective treatment. (See Phillips, T. J., Proc. Roy. Soc. Med., Sect. Ophthal., Vol. XXXIII, Jan. 25, 1940.)

LoNDON, July 4, 1940.

\section{OBITUARY}

\section{SIR GEORGE BERRY}

Sir George Andreas Berry, LL.D., F.R.C.S.E., died at his residence, "King's Knoll," North Berwick, on June 18, in his 87 th year.

George Berry was the eldest son of Walter Berry of Glenstriven, Argyllshire. Born in 1853, he was educated at Marlborough and at Edinburgh. He studied mathematics under Professor Tait, and became one of the six members of Tait's Senior Class, where he developed his remarkable knowledge of this subject. He graduated M.B., C.M. at Edinburgh in 1876, and in 1981 became a Fellow of the Royal College of Surgeons of Edinburgh.

Before beginning practice George Berry prosecuted his special studies in ophthalmology for some years in various Universities and Hospitals. In Copenhagen he worked with his distinguished uncle, Professor Hansen Grut, who later became Bowman Lecturer of the Ophthalmological Society of the United Kingdom in 1889, and for whom he retained throughout his life the greatest admiration and regard. He also studied in France, Austria, Germany and Holland at this period of his career.

While he was House Surgeon at Moorfields Eye Hospital, London, in 1878-1879, Berry was one of the moving spirits in the formation of the Ophthalmological Society of the United Kingdom, which was founded in 1880 . Throughout his lifetime he took the greatest interest in this Society, of which he was an Original Member. 